\title{
HONEYBEE (APIS MELLIFERA) MEDIATED INCREASED REPRODUCTIVE SUCCESS OF A RARE DECEPTIVE ORCHID
}

\author{
BIRÓ, É. ${ }^{1}$ - BÓDIS, J. ${ }^{1}$ - NAGY, T. ${ }^{1}$ - TÖKÖLYI, J. ${ }^{3}-$ MOLNÁR V., A. ${ }^{2} *$ \\ ${ }^{I}$ Department of Plant Sciences and Biotechnology, University of Pannonia, \\ Georgikon Faculty, \\ H-8360 Keszthely, Festetics u. 7., Hungary, \\ (phone: +36-83-545-095; fax: +36-83-545-058); \\ ${ }^{2}$ Department of Botany, University of Debrecen, \\ Egyetem tér 1., H-4032, Debrecen, Hungary, \\ (phone: +36-52-512-900 /62632; fax: +36-52-512-943) \\ 3 'Lendület' Behavioural Ecology Research Group, Department of Evolutionary Zoology, \\ University of Debrecen, \\ Egyetem tér 1., H-4032 Debrecen, Hungary, \\ (phone: +36-52-512-900 /62331; fax: +36-52-512-941) \\ *Corresponding author \\ e-mail:mva@science.unideb.hu
}

(Received 9th January 2014; accepted 15th May 2014)

\begin{abstract}
Honeybees are the most numerous and significant among insect pollinators, but despite their significance their potential role in increasing the reproductive success of threatened European orchids remains largely unexplored. In this study we aim to evaluate the effect of apiary proximity on the fructification rate of the rare and endangered Adriatic Lizard Orchid (Himantoglossum adriaticum $\mathrm{H}$. Baumann). To do so, first we quantified the reproductive success (fruit set) of the Adriatic Lizard Orchids in a Hungarian population in close proximity to a honeybee apiary at Nagytevel. Then we compared the reproductive success in this population to the reproductive success in 3 other Hungarian, 4 Croatian populations (observed during the same year, 2013) and further 4 populations from Hungary (studied in previous years, 1992-2011) with no apiaries in the close proximity of these. The realised $61.7 \%$ fruit set at Nagytevel is the highest reproductive success ever recorded for this species. The importance of apiaries is further emphasised by the fact that the reproductive success of Lizard Orchid individuals decreased significantly with increasing distance from the apiary. Our results provide empirical support for the conservation importance of apiculture and suggest promising results for practical application of apiaries in the conservation of of deceptively pollinated orchids characterised by lower fruit set (e.g. Orchis, Anacamptis, Himantoglossum).
\end{abstract}

Keywords: apiculture, fruit set, Himantoglossum adriaticum, pollination crisis, Orchidaceae

\section{Introduction}

The family Orchidaceae, with its more than 25,000 species, is one of the largest in the plant kingdom (Dressler, 1993). Despite their world-wide dispersion and extreme plasticity, the majority of these species are of key conservation importance (Jacquemyn et al., 2005; Kull and Hutchings, 2006; Swarts and Dixon; 2009). Causes of their decline are complex, but - independently of the conservation status - the long-term persistence of plant populations in every case partly depends on seed production.

The reproductive success of entomophilous orchids depends on the effectiveness of pollination processes, namely; pollinator attraction, pollen sack removal and its deposition on conspecific flower. Such interactions have immediate consequences for

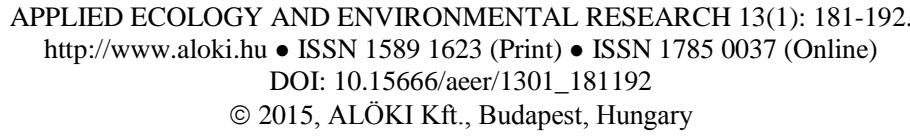


endangered Spiranthes species, as increases in both conspecific and heterospecific coflowering density may ameliorate the negative effects of rarity on pollination, hence overall reproductive success (Duffy and Stout, 2011). Lack of suitable insects to pollinate the flowers of Orchis militaris has been characteristic of British populations since the beginning of 19th century according to herbaria data (Farrell, 1985). Similar low fruit set were detected at the beginning of 20th century in Germany (Sprengel, reported by Godfrey 1933).

The flowers of deceptive (i.e. non-rewarding) orchids usually experience very low pollinator visitation rates that will result in low levels of fruit set compared to rewarding orchids (Dafni and Ivri, 1979; Gill, 1989; Neiland and Wilcock, 1999; Harder and Johnson, 2008). Deception is not rare among the orchids, it is estimated that as much as one-third of orchid species use various forms of floral deception to attract pollinators (Dafni, 1984; Ackerman, 1986; Jersáková et al., 2006).

In temperate climate regions the most important pollinators are insects, among which bees predominate. It was the finding of the last decades that bees in parallel with insectpollinated plants are declining on both western European (Biesmeijer et al., 2006) and global scales (Allen-Wardell et al., 1998; Kearns et al., 1998; Potts et al., 2010). The major threat to bee diversity is habitat loss, but competitive invasive species, newly emerging diseases, extensive use of pesticides, and climate change also have the potential to negatively impact bee population sizes (Brown and Paxton, 2009; Brittain and Potts, 2011). Bees require a large number of flowers to gather enough nectar and pollen to support the hive, and also need a large variety of flowering plants with different flowering times to provide them continuous food supplies throughout the growing season (Kearns and Inoyue, 1997). However, due to the relatively recent change in land-use practices, the nectar sources for bees, characteristic to fragmented landscapes have greatly diminished in recent years (Feon et al., 2013).

Despite the dominant individual number of honeybee in the bee assemblages and their importance in pollination, the potential role in the reproductive success of European orchids remains largely unclear.

The aim of the present study was to evaluate the role of apiculture in increasing the reproductive success of the rare and endangered Adriatic Lizard Orchid (Himantoglossum adriaticum Baumann). Red Data Books of most countries where it occurs (Conti et al., 1997; Király 2007; Maglocky and Feráková, 1993; Grulich, 2012). The conservation status of the species is Critically Endangered in the Czech Republic and in Slovakia, Endangered in Austria and in Hungary, Vulnerable in Slovenia and Near Threatened in Croatia (Dostalova et al., 2011). Additionally H. adriaticum is suffering ongoing population declines and is listed in the Annex II of Council Directive 92/43/EEC (the 'Habitats Directive').

The reproductive success of Himantoglossum adriaticum is generally low. Previously published fruit set data varied between 4.5 and $44 \%$ in Austria (Vöth, 1990), and between 5.4\% and 23.3\% in Hungary (Bódis and Molnár, 2009).

We measured reproductive success (fruit set) in a population of Adriatic Lizard Orchid in close proximity to a honeybee colony and compared it with other populations observed during the same year without bees and four populations studied in previous years.

An apiary, composed of 174 hives hosting Apis mellifera colonies in 4 containers was located on the study site at Nagytevel (Hungary) between $25^{\text {th }}$ May and $05^{\text {th }}$ July 2013 (coinciding with the flowering time of Himatoglossum orchids). The distance of 
the hives from flowering Himantoglossum plants varied between 196-1455 meters. All studied $H$. adriaticum flowering specimens were situated within the effective foraging radius (1.5-3 km, Frisch, 1965; Bagella et al., 2013) of honeybees in Europe. To the best of our knowledge, no apiaries were present in the vicinity of this population in other years, nor in the rest of populations studied here.

We specifically stated the following study questions: (i) Is there significant effect of the apiary on the reproductive success of $H$. adriaticum population, living within the foraging distance of honeybee? (ii) Is there correlation between the individual reproductive success (fruit set) and the distances from the apiary?

\section{Materials and methods}

\section{Study species}

Himantoglossum adriaticum $\mathrm{H}$. Baumann has a central submediterranean distribution, currently known to occur in Croatia, Slovenia, northern and central Italy, eastern Austria, western Slovakia and Hungary (Pecoraro et al., 2013, Rybka et al., 2005).

The characteristic habitat of the species is full sun to mid-shade and dry calcareous substrates. It prefers poor grassland, banks, thickets, woodland edges and open woodlands, up to 1600 meters of altitude above sea level (Delforge, 2006), relatively often occuring in secondary habitats, e.g. abandoned vine-yards, extensively used orchards and mown grassy verges on the sides of public roads (Molnár, 2011). The Adriatic Lizard Orchid is a terrestrial, tuberous photoautotrophic orchid with overwintering rosette, which consists of 2-7 large, lanceolate, pale green basal leaves. The generative shoots are $30-80 \mathrm{~cm}$ tall, the inflorescence is elongated and lax, composed of 15-40 brownish red, typically malodorous flowers. The lip is deeply 3lobed, the median lobe is long, ribbon-like, incised (Delforge, 2006; Molnár, 2011). The flowers have been observed to be pollinated by the following bee species: Andrena haemorrhoa, A. carbonaria, A. nigroaenea, A. potentillae, Apis mellifera (Claessens and Kleynen, 2011), Colletes similis (Vöth, 1990; Sulyok et al., 1998), Bombus spp. (Teschner, 1980), Osmia caerulescens, Lasioglossum (Evylaeus) morio, Lasioglossum (Evylaeus) lucidulum, Megachile melanopyga (Bódis, 2010).

\section{Measuring reproductive success}

Eight populations of Himantoglossum adriaticum were studied in Hungary and Croatia in 2013 (Table 1).

Table 1. Adriatic Lizard Orchid populations studied in 2013. $n$ : total number of undamaged fruiting shoots observed; Date of observation: flowering and fruiting sampling.

\begin{tabular}{|c|c|c|c|c|c|}
\hline No. & Country & Locality & $\mathbf{n}$ & Date of observation & Geocoordinates \\
\hline 1 & Hungary & Nagytevel & 39 & $20^{\text {th }}$ June; $31^{\text {st }}$ July & $\mathrm{N} 47.264^{\circ}, \mathrm{E} 17.598^{\circ}$ \\
\hline 2 & Hungary & Köszeg & 36 & $19^{\text {th }}$ June.; $13^{\text {rd }}$ July & $\mathrm{N} 47.375^{\circ}, \mathrm{E} 16.526^{\circ}$ \\
\hline 3 & Hungary & Keszthely & 33 & $15^{\text {th }}$ June; $14^{\text {th }}$ July. & $\mathrm{N} 46.794^{\circ}, \mathrm{E} 17.277^{\circ}$ \\
\hline 4 & Hungary & Sümeg & 47 & $17^{\text {th }}$ June; $13^{\text {rd }}$ July & $\mathrm{N} 46.957^{\circ}, \mathrm{E} 17.351^{\circ}$ \\
\hline 5 & Croatia & Učka & 88 & $2^{\text {nd }}-3^{\text {rd }}$ June $; 8^{\text {th }}-9^{\text {th }}$ July & $\mathrm{N} 45.317^{\circ}, \mathrm{E} 14.175^{\circ}$ \\
\hline 6 & Croatia & $\mathrm{Paz}$ & 7 & $4^{\text {th }}$ June; $9^{\text {th }}$ July & $\mathrm{N} 45.277^{\circ}, \mathrm{E} 14.104^{\circ}$ \\
\hline 7 & Croatia & Letaj I. & 14 & $4^{\text {th }}$ June; $9^{\text {th }}$ July & $\mathrm{N} 45.255^{\circ}, \mathrm{E} 14.121^{\circ}$ \\
\hline 8 & Croatia & Letaj II. & 12 & $4^{\text {th }}$ June; $9^{\text {th }}$ July & $\mathrm{N} 45.255^{\circ}, \mathrm{E} 14.132^{\circ}$ \\
\hline
\end{tabular}


All generative shoots were individually marked with labelled nail. The number of flowers on each specimen was recorded during the first visits on each site (between $2^{\text {th }}$ and $20^{\text {th }}$ June), while the number of developed fruits was counted 3-5 weeks later (between $8^{\text {th }}$ and $31^{\text {st }}$ July). Shoots which were damaged during the flowering period were excluded from the analyses. Reproductive success was defined as fructification rate: total number of fruits in the population divided by the total number of flowers in the given population on a given specimen; in other terms fruit set. The reproductive success of populations were compared to data on the fructification rate of the same species collected in earlier years using the same methodology (Table 2). The reproductive success means in every case population level.

Table 2. Adriatic Lizard Orchid populations studied between 1992-2011. n: total number of undamaged fruiting shoots observed in a given population.

\begin{tabular}{l|l|c|c|c}
\hline No. & Country & Locality & Study period & $\mathbf{n}$ \\
\hline 1 & Hungary & Nagytevel & 2010,2011 & 11,41 \\
2 & Hungary & Köszeg & 2010,2011 & 33,18 \\
3 & Hungary & Keszthely & $1992-2011$ & $17-73$ \\
4 & Hungary & Sümeg & $2002,2003,2008-2011$ & $76,19,25-49$ \\
\hline
\end{tabular}

\section{Data analyses}

To compare the reproductive success of different populations we employed a generalized linear model (GLM) with quasibinomial error structure. This approach was necessary because fruit set (the measure of reproductive success) is a binomial variable (it takes values between 0 and 1) and samples were not uniformly distributed within this interval (in several populations most plants had fruit sets close to 0); quasibinomial models take into account such overdispersion in the data. The relationship between distance to the apiary and fruit set was also evaluated using a quasibinomial GLM. GLMs were implemented in the R Statistical Environment (R Core Team, 2013).

\section{Results}

Reproductive success varied considerably both among sites and among years within specific sites (Table 3). Average fructification rate was under $10 \%$ in Učka and Keszthely, between 10-20\% in Letaj, little above 20\% in Sümeg and Paz, little above $30 \%$ in Köszeg and outstandingly high (61.7\%) at Nagytevel in 2013. The number of flowering individuals was not associated with the measured reproductive success, but the largest population (Učka) had the lowest fruit set.

The average reproductive success of the $H$. adriaticum population at Nagytevel in 2013 was significantly higher than in other population studied by us (both 2013 and earlier years), with three exceptions: Nagytevel 2010, Keszthely 2004 and Sümeg 2003 (Table 4).

The importance of apiaries in the pollination of Lizard Orchids is also shown by our observation that individual reproductive success in the population at Nagytevel decreased significantly with increasing distance from the apiary (quasibinomial GLM $\mathrm{F}_{1,39}=18.52$, $\mathrm{p}<0.001$, Fig. 1.). 
Table 3. Reproductive success of populations studied in 2013 and in earlier years. $n$ : total number of undamaged fruiting shoots observed in a given population.

\begin{tabular}{|c|c|c|c|c|c|}
\hline Locality & Year & $\mathbf{n}$ & No. of flowers & No. of fruits & $\begin{array}{c}\text { Fructification } \\
\text { rate }(\%)\end{array}$ \\
\hline Nagytevel & 2013 & 41 & 1477 & 911 & 61.7 \\
\hline Köszeg & 2013 & 36 & 1256 & 396 & 31.5 \\
\hline Sümeg & 2013 & 54 & 1657 & 356 & 21.5 \\
\hline Keszthely & 2013 & 32 & 1105 & 105 & 9.5 \\
\hline Učka & 2013 & 100 & 2965 & 259 & 8.7 \\
\hline Letaj I. & 2013 & 16 & 462 & 64 & 13.9 \\
\hline Letaj II. & 2013 & 12 & 422 & 77 & 18.2 \\
\hline $\mathrm{Paz}$ & 2013 & 7 & 210 & 44 & 21 \\
\hline Nagytevel & 2010 & 11 & 227 & 118 & 52 \\
\hline Nagytevel & 2011 & 41 & 1101 & 166 & 15.1 \\
\hline Sümeg & 2002 & 76 & 2326 & 633 & 27.2 \\
\hline Sümeg & 2003 & 19 & 486 & 256 & 52.7 \\
\hline Sümeg & 2008 & 32 & 1009 & 242 & 24 \\
\hline Sümeg & 2009 & 29 & 849 & 358 & 42.2 \\
\hline Sümeg & 2010 & 25 & 640 & 179 & 28 \\
\hline Sümeg & 2011 & 49 & 1337 & 281 & 21 \\
\hline Kőszeg & 2010 & 33 & 1300 & 549 & 42.2 \\
\hline Kőszeg & 2011 & 18 & 406 & 92 & 22.7 \\
\hline Keszthely & 1992 & 25 & 909 & 171 & 18.8 \\
\hline Keszthely & 1993 & 17 & 544 & 51 & 9.4 \\
\hline Keszthely & 1994 & 19 & 671 & 36 & 5.4 \\
\hline Keszthely & 1995 & 73 & 2758 & 219 & 7.9 \\
\hline Keszthely & 1996 & 67 & 2130 & 342 & 16.1 \\
\hline Keszthely & 1997 & 23 & 686 & 58 & 8.5 \\
\hline Keszthely & 1998 & 30 & 975 & 197 & 20.2 \\
\hline Keszthely & 1999 & 31 & 971 & 96 & 9.9 \\
\hline Keszthely & 2000 & 12 & 333 & 19 & 5.7 \\
\hline Keszthely & 2001 & 10 & 315 & 21 & 6.7 \\
\hline Keszthely & 2002 & 32 & 912 & 156 & 17.1 \\
\hline Keszthely & 2003 & 19 & 642 & 161 & 25.1 \\
\hline Keszthely & 2004 & 20 & 524 & 286 & 54.6 \\
\hline Keszthely & 2005 & 55 & 1736 & 297 & 17.1 \\
\hline Keszthely & 2006 & 21 & 601 & 207 & 34.4 \\
\hline Keszthely & 2007 & 21 & 530 & 187 & 35.3 \\
\hline Keszthely & 2008 & 33 & 1040 & 128 & 12.3 \\
\hline Keszthely & 2009 & 23 & 579 & 61 & 10.5 \\
\hline Keszthely & 2010 & 12 & 267 & 10 & 3.7 \\
\hline Keszthely & 2011 & 29 & 738 & 61 & 8.3 \\
\hline
\end{tabular}

\section{Discussion}

The average reproductive success of the studied Lizard orchid populations was independent of the size of the population. A similar phenomenon was detected in the case of another nectarless orchid, Orchis mascula, where fruit set was low even in large populations in highly fragmented calcareous grassland in southern Belgium (Meekers and Honnay, 2011).I In that area the percentage fruit set of same species was 
independent from population size in undisturbed woodland but strongly related to population size in coppiced woodland (Jacquemyn et al., 2008). Fruit set was positively related to population size in the nectar producing Gymnadenia conopsea too (Meekers and Honnay, 2011). In contrast definitely reduced fecundity was observed in large populations of a nectar-rewarding species, Spiranthes spiralis (Petanidou et al., 2013). Fruit set in small populations of non-rewarding Orchis purpurea increased with population size (and decreased with increasing nearest-neighbour distance) (Jacquemyn et al., 2002).

Table 4. Parameter estimates, their standard errors, $t$-values and significance levels from the quasibinomial GLM comparing reproductive success of the Nagytevel 2013 population (the intercept of the model) to other samples. Reproductive success was significantly lower in other populations / years, except for the Keszthely 2004, Nagytevel 2010 and Sümeg 2003 samples.

\begin{tabular}{l|c|c|c|c}
\hline Locality / Year & Estimate & Standard Error & t value & p value \\
\hline Letaj II.-2013 & -1.976 & 0.353 & -5.603 & 0.000 \\
Paz-2013 & -1.804 & 0.458 & -3.940 & 0.000 \\
Letaj I.-2013 & -2.304 & 0.373 & -6.173 & 0.000 \\
Učka-2013 & -2.303 & 0.194 & -11.857 & 0.000 \\
Keszthely-2013 & -2.730 & 0.298 & -9.162 & 0.000 \\
Sümeg-2013 & -1.779 & 0.198 & -9.008 & 0.000 \\
Köszeg-2013 & -0.429 & 0.215 & -2.000 & 0.046 \\
Keszthely-1992 & -1.938 & 0.258 & -7.502 & 0.000 \\
Keszthely-1993 & -2.745 & 0.403 & -6.810 & 0.000 \\
Keszthely-1994 & -3.346 & 0.462 & -7.240 & 0.000 \\
Keszthely-1995 & -2.685 & 0.214 & -12.524 & 0.000 \\
Keszthely-1996 & -1.931 & 0.198 & -9.743 & 0.000 \\
Keszthely-1997 & -2.858 & 0.379 & -7.535 & 0.000 \\
Keszthely-1998 & -1.849 & 0.247 & -7.478 & 0.000 \\
Keszthely-1999 & -2.686 & 0.309 & -8.685 & 0.000 \\
Keszthely-2000 & -3.281 & 0.624 & -5.260 & 0.000 \\
Keszthely-2001 & -3.115 & 0.598 & -5.212 & 0.000 \\
Keszthely-2002 & -2.054 & 0.265 & -7.749 & 0.000 \\
Keszthely-2003 & -1.570 & 0.272 & -5.775 & 0.000 \\
Keszthely-2004 & -0.292 & 0.265 & -1.104 & 0.270 \\
Keszthely-2005 & -2.054 & 0.214 & -9.584 & 0.000 \\
Keszthely-2006 & -1.120 & 0.260 & -4.298 & 0.000 \\
Keszthely-2007 & -1.083 & 0.272 & -3.986 & 0.000 \\
Keszthely-2008 & -2.440 & 0.279 & -8.732 & 0.000 \\
Keszthely-2009 & -2.615 & 0.375 & -6.977 & 0.000 \\
Keszthely-2010 & -3.722 & 0.841 & -4.425 & 0.000 \\
Keszthely-2011 & -2.883 & 0.371 & -7.775 & 0.000 \\
Köszeg-2010 & -0.789 & 0.200 & -3.951 & 0.000 \\
Köszeg-2011 & -1.704 & 0.335 & -5.086 & 0.000 \\
Nagytevel-2010 & -0.397 & 0.369 & -1.075 & 0.282 \\
Nagytevel-2011 & -2.205 & 0.257 & -8.579 & 0.000 \\
Sümeg-2002 & -1.024 & 0.177 & -5.791 & 0.000 \\
Sümeg-2003 & -0.369 & 0.272 & -1.359 & 0.175 \\
Sümeg-2008 & -1.629 & 0.235 & -6.946 & 0.000 \\
Sümeg-2009 & -0.792 & 0.226 & -3.506 & 0.000 \\
Sümeg-2010 & -1.422 & 0.265 & -5.359 & 0.000 \\
Sümeg-2011 & 0.221 & -8.142 & 0.000 \\
\hline & & & \\
\hline
\end{tabular}




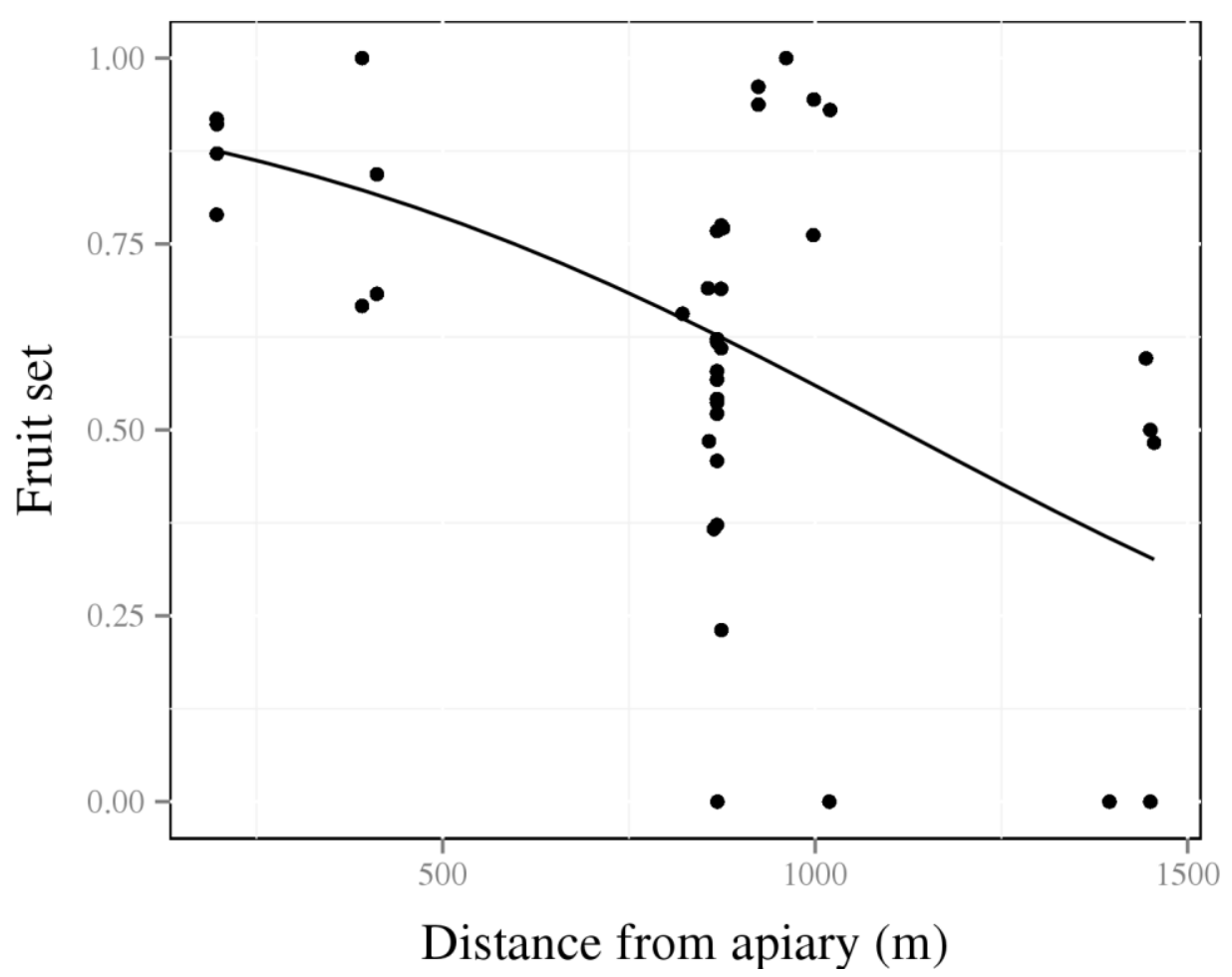

Figure 1. Relationship between individual distance from apiary and fruit set in Adriatic Lizard Orchids at Nagytevel (2013).

The realised $61.7 \%$ fructification rate in Nagytevel is the highest ever published population-level average reproductive success of $H$. adriaticum, although this was not significantly higher than the 52-54.6\% reproductive success observed in three other populations in Hungary during earlier years. Overall average fruit set values of nectarless and nectariferous European orchids are $28 \%$ and $63 \%$, respectively (Neiland and Wilcock, 1999) implying that the Himantoglossum population at Nagytevel reached the average fructification level of rewarding orchids.

Our results also show that the reproductive success of individual flowers in this population was negatively related to their distance from the beehives. Together, these results strongly suggest that honeybees were causally implicated in the high reproductive success of this population in 2013. Abundance of flower visiting honeybees depends on the distance from the nearest apiary in agricultural landscapes (Steffan-Dewenter and Tscharntke, 1999). Because the diversity of pollinators declines rapidly, the role of honeybees in pollination increases strongly (Brown and Paxton, 2009; Potts et al., 2010).

Frequent pollinators of $H$. adriaticum include both social (Bombus spp.) and solitary bees (Andrena spp., Colletes similis, Osmia caerulescens, Megachile melanopyga, Lasioglossum spp.). These are common species and forage on a wide variety of plant species. In arable field-margins in western France the most common pollinator species were Andrena and Lasioglossum (Féon et al., 2013), while near Göttingen in Germany, in an intensively managed agricultural landscape with islands of semi-natural calcareous grasslands Osmia and Megachile bee species were common pollinators (SteffanDewenter and Tscharntke, 2000). 
Bee and insect-pollinated plant species richness was highest in Hungary when compared to Switzerland and the Netherlands. The richness of insect-pollinated plants is a good predictor of bee species richness across large geographic scales (Batáry et al., 2010).

Despite of relatively high species richness of bees and flowering plants in Hungary the pollination effect of honeybees was significant in Nagytevel. We can not exclude, however, that the earlier high fruit set data from Hungary were caused by honeybees. On the one hand average bee density is continuously increasing in Hungary: there were 7.78 honeybee colonies $/ \mathrm{km}^{2}$ in 1992 and 12.18 in 2012. On the other hand average bee density can strongly vary regionally (Tóth, 2013).

According to published data, honeybees are common pollinators of 21 fooddeceptive and 12 nectar rewarding European terrestrial orchids (Table 5), mostly from the genera Anacamptis and Orchis (6-6 species), Dactylorhiza (5 species), Epipactis, Gymnadenia and Himantoglossum (3-3 species).

Table 5. Literature data about pollination European orchids by honeybees.

\begin{tabular}{|c|c|c|}
\hline Species & Pollination & Source \\
\hline Anacamptis boryi & Food-deceptive & Gumbert and Kunze 2001 \\
\hline Anacamptis coriophora & Nectar rewarding & Berger 2004 \\
\hline Anacamptis coriophora subsp. fragrans & Nectar rewarding & Peisl and Forster 1975 \\
\hline Anacamptis morio & Food-deceptive & Darwin 1877 \\
\hline Anacamptis palustris & Food-deceptive & Sulyok in Molnár 2011 \\
\hline Anacamptis papilionacea & Food-deceptive & Vöth $1989 a$ \\
\hline Anacamptis pyramidalis & Food-deceptive & Vöth 1999 \\
\hline Dactylorhiza fuchsii & Food-deceptive & Reinhard et al.1991 \\
\hline Dactylorhiza ochroleuca & Food-deceptive & Bournérias and Prat 2005 \\
\hline Dactylorhiza sambucina & Food-deceptive & Nilsson 1980 \\
\hline Dactylorhiza sphagnicola & Food-deceptive & Claessens and Kleynen 2011 \\
\hline Dactylorhiza sudetica & Food-deceptive & Berger 2005 \\
\hline Epipactis atrorubens & Nectar rewarding & Wiefelspütz 1970 \\
\hline Epipactis helleborine & Nectar rewarding & Müller 1988 \\
\hline Epipactis palustris & Nectar rewarding & Darwin 1877 \\
\hline Goodyera repens & Nectar rewarding & Claessens and Kleynen 2013 \\
\hline Gymnadenia corneliana & Nectar rewarding & Berger 2009 \\
\hline Gymnadenia lithopolitanica & Nectar rewarding & Vöth 2000 \\
\hline Gymnadenia nigra s.l. & Nectar rewarding & Godfrey 1933 \\
\hline Himantoglossum jankae & Food-deceptive & Teschner 1980 \\
\hline Himantoglossum adriaticum & Food-deceptive & Vöth 1990 \\
\hline Neotinea tridentata & Food-deceptive & Vöth $1989 b$ \\
\hline Neottia ovata & Nectar rewarding & Nilsson 1981 \\
\hline Orchis italica & Food-deceptive & Vöth 1998 \\
\hline Orchis mascula & Food-deceptive & Darwin 1877 \\
\hline Orchis militaris & Food-deceptive & Vöth 1999 \\
\hline Orchis ovalis & Food-deceptive & Vöth 1999 \\
\hline Orchis purpurea & Food-deceptive & Godfrey 1933 \\
\hline Orchis simia & Food-deceptive & Godfrey 1933 \\
\hline Spiranthes romanzoffiana & Nectar rewarding & Larson and Larson 1987 \\
\hline Spiranthes spiralis & Nectar rewarding & Petanidou et al. 2013 \\
\hline Traunsteinera globosa & Food-deceptive & Vöth 1994 \\
\hline
\end{tabular}

Based on our findings the practical application of apiaries in orchid conservation (for increasing reproductive success) seems to be promising, especially in the case of 
deceptive orchids, which are characterized by a low flower visitation rate by pollinators and therefore by a low fruit set.

On the one hand, honeybees have been assumed to be superior competitors because of the high nectar and pollen requirements of their large perennial colonies compared to solitary bees. Furthermore they are believed to rapidly exploit rich patches of flowering plants using their dance language to communicate direction and distance of food resources to other foragers (Frisch, 1965; Visscher and Seeley, 1982; Beekman and Ratnieks, 2000). On the other hand, apiculture does not appear to have a negative impact on wild bees: neither species richness nor abundance of wild bees was negatively correlated with the density of honeybee colonies (within a radius of $2 \mathrm{~km}$ ) or the density of flower-visiting honeybees per site despite the assumed competition between them (Steffan-Dewenter and Tscharntke, 2000). The positive impact of increased honeybee amounts to the reproductive success of wild plants is not always well supported by empirical data (Klein et al., 2007). Our results based on reproductive success of deceptively pollinated orchid are confirming those opinions, that honeybees apart from being among the most important pollinators of agricultural crops, they also provide important pollination services to wild plants.

Acknowledgements. The authors would like to thank Katalin Molnár, Anna Németh, Zsuzsanna Sándor and Attila Takács for their help during the fieldwork and Orsolya Vincze for her comments and linguistic corrections. This research was supported by the European Union and the State of Hungary, co-financed by the European Social Fund in the framework of TÁMOP-4.2.4.A/2-11/1-2012-0001 'National Excellence Program'. The instrumental and infrastructural support of OTKA K108992 Grant is also highly appreciated.

\section{REFERENCES}

[1] Ackerman, J.D. (1986): Mechanisms and evolution of food-deceptive pollination systems in orchids. - Lindleyana 1: 108-113.

[2] Allen-Wardell, G., Bernhardt, P., Bitner, R., Burquez, A., Buchmann, S., Cane, J., Cox, P.A., Dalton, V., Feinsinger, P., Ingram, M., Inouye, D., Jones, E., Kennedy, K., Kevan, P., Koopowitz, H., Medellin, R., Medellin-Morales, S., Nabhan, P., Pavlik, B., Tepedino, V., Torchio, P., Walker, S. (1998): The potential consequences of pollinator declines on the conservation of biodiversity and stability of food crop yields. - Conservation Biology 12: 8-17.

[3] Bagella S., Satta A., Floris I., Caria M.C., Rossetti I., Podani J. (2013): Effects of plant community composition and flowering phenology on honeybee foraging in Mediterranean sylvo-pastoral systems. - Applied Vegetation Science 16: 688-697.

[4] Batáry, P., Báldi, A., Sárospataki, M., Kohler, F., Verhulst, J., Knop, E., Hercog, F., Kleijn, D. (2010): Effect of conservation management on bees and insect-pollinated grassland plant communities in three European countries. - Agriculture, Ecosystems and Environment 136(1): 35-39.

[5] Beekman, M., Ratnieks, F.L.W. (2000): Long-range foraging by the honey-bee, Apis mellifera L. - Functional Ecology 14: 490-496.

[6] Berger, L. (2004): Observations sur le comportement da quelques pollinisateurs d'orchidées ( $3^{\mathrm{e}}$ partie). - L'Orchidophile 160: 19-35.

[7] Berger, L. (2005): Quelques interrogations sur la pollinisation des Dactylorhiza. - Bull. SFO - Rhône-Alpes 12: 23-22.

[8] Berger, L. (2009): La pollinisation du genre Nigritella (L.C.M. Richard). - Journal Europäischer Orchideen 41: 411-432. 
[9] Biesmeijer, J.C., Roberts, S.P.M., Reemer, M., Ohlemüller, R., Edwards, M., Peeters, T., Schaffers, A.P., Potts, S.G., Kleukers, R., Thomas, C.D., Settele, J., Kunin, W.E. (2006): Parallel declines in pollinators and insect-pollinated Plants in Britain and the Netherlands. - Science 313: 351-354.

[10] Bódis, J. (2010): Himantoglossum adriaticum populációk dinamikája: demográfiai és életmenet jellemzők [Variaton of demography and life history characteristics in Himantoglossum adriaticum populations] (in Hungarian). - PhD Theses. Biológiai Doktoriskola, Pécsi Tudományegyetem, Pécs.

[11] Bódis, J., Molnár, E. (2009): Long-term monitoring of Himantoglossum adriaticum H. Baumann population in Keszthely Hills, Hungary. - Natura Somogyiensis 15: 27-40.

[12] Bournérias, M., Prat, D. (2005): Les Orchidées de France, Belgique et Luxembourg. $2^{\mathrm{e}}$ édition. - Biotope, Mèze. 504 pp.

[13] Brittain, C., Potts, S. G. (2011): The potential impacts of insecticides on the life-history traits of bees and the consequences for pollination. - Basic and Applied Ecology 12: 321331.

[14] Brown, M.J., Paxton, R.J. (2009): The conservation of bees: a global perspective. Apidologie 40(3): 410-416.

[15] Claessens, J., Kleynen, J. (2011): The flower of the European orchid. Form and function. - Claessens and Kleynen, Geuelle. 440 pp.

[16] Claessens, J., Kleynen, J. (2013): Honigbienen (Apis mellifera) als Bestäuber von Goodyera repens. - Journal Europäischer Orchideen 45(1): 133-138.

[17] Conti, F, Manzi A., Pedrotti F. (1997): Liste rosse regionali delle piante d'Italia. WWF/Società Botanica Italiana, Camerino.

[18] Dafni, A (1984): Mimicry and deception in pollination. - Annual Review of Ecology, Evolution, and Systematics 15: 259-278

[19] Dafni, A., Ivri, Y. (1979): Pollination ecology of, and hybridisation between, Orchis coriophora L. and O. collina Sol. ex Russ. (Orchidaceae) in Israel. - New Phytologist 83: 181-187.

[20] Darwin, C. (1877): On the various contrivances by which British and foreign orchids are fertilised by insects. - J. Murray, London.

[21] Delforge, P. (2006): Orchids of Europe, North Africa and Middle East. - AandC Black, London.

[22] Dostalova, A., Montagnani, C., Hodálová, I., Jogan, N., Király, G., Ferakova, V. and Bernhardt, K.G. (2011): Himantoglossum adriaticum. In: IUCN 2013. IUCN Red List of Threatened Species. Version 2013.2. www.iucnredlist.org. (Downloaded on 16 December 2013.)

[23] Dressler, R. L. (1993): Phylogeny and classification of the orchid family. - Cambridge University Press, Cambridge.

[24] Duffy, K.J., and Stout, J.C. (2011): Effects of conspecific and heterospecific floral density on the pollination of two related rewarding orchids. - Plant Ecology 212: 13971406.

[25] Farrell L. (1985): Orchis militaris L. Biological Flora of tje British Isles. Journal of Ecology. - 73:1041-1053.

[26] Féon, V.L., Burel, F, Chifflet, R., Henry, M., Ricroch, A., Vaissičre, B.E., Baudry, J. (2013): Solitary bee abundance and species richness in dynamic agricultural landscapes. Agriculture, Ecosystems and Environment 166: 94-101.

[27] Frisch, K. von (1965): Tanzsprache und Orientierung der Bienen. - Springer, Berlin Heidelberg, New York.

[28] Gill, D.E. (1989): Fruiting failure, pollinator inefficiency, and speciation in orchids. In: Otte, D., Endler, J.A. (eds.) Speciation and Its Consequences. - Sinauer Associetes, Sunderland, MA, pp. 458-481.

[29] Godfrey, M. J. (1933): Monograph and Iconography of Native British Orchidaceae. Cambridge University Press, Cambridge. 259 pp.

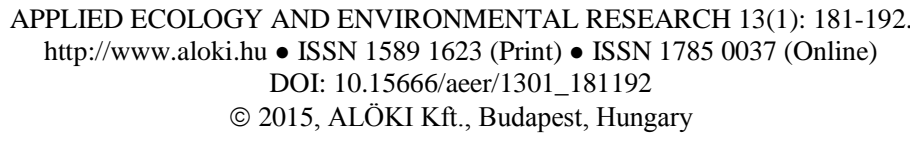


[30] Grulich, V. (2012): Red List of vascular plants of the Czech Republic. - Preslia 84: 631645.

[31] Gumbert, A., Kunze, J. (2001): Colour similarity to rewarding model plants affects pollination in a food deceptive orchid, Orchis boryi. - Biological Journal of the Linnean Society 72: 419-433.

[32] Harder, L.D., Johnson, S. D. (2008): Function and evolution of aggregated pollen in angiosperms. - International Journal of Plant Sciences 169: 59-78.

[33] IUCN (2013): IUCN Red List of Threatened Species. Version 2013.1. <www.iucnredlist.org>. Downloaded on 05th November 2013.

[34] Jacquemyn, H., Brys, R., Hermy, M. (2002): Flower and fruit production in small populations of Orchis purpurea and implications for management. In: Kindlmann, P., Willems, J., Whigham, D. F. (eds.): Trends and fluctuations and underlying mechanisms in terrestrial orchid populations. - Backhuys Publishers, Leiden, pp. 67-84.

[35] Jacquemyn, H., Brys, R., Hermy, M., Willems, J.H. (2005): Does nectar reward affect rarity and extinction probabilities of orchid species? An assessment using historical records from Belgium and the Netherlands. - Biological Conservation 121(2): 257-263.

[36] Jacquemyn, H., Brys, R., Honnay, O., and Hermy, M. (2008): Effects of coppicing on demographic structure, fruit and seed set in Orchis mascula. - Basic and Applied Ecology, 9(4): 392-400.

[37] Jersáková, J., Johnson, S.D., Kindlmann, P. (2006): Mechanisms and evolution of deceptive pollination in orchids. - Biological Reviews 81: 219-235.

[38] Kearns, C.A, Inouye, D.W. (1997): Pollinators, flowering plants, and conservation biology. - Bioscience 47: 297-306

[39] Kearns, C.A., Inouye, D.W., Waser, N.M. (1998): Endangered mutualisms: the conservation of plant-pollinator interactions. - Annual Review of Ecology, Evolution, and Systematics 29: 83-112.

[40] Király, G. (ed., 2007): Vörös Lista. A magyarországi edényes flóra veszélyeztetett fajai. Red list of the vascular flora of Hungary. - Private edition, Sopron, p. 73.

[41] Klein, A.M., Vaissiere, B.E., Cane, J.H., Steffan-Dewenter, I., Cunningham, S.A., Kremen, C., Tscharntke T. (2007): Importance of pollinators in changing landscapes for world crops. - Proceedings of the Royal Society B - Biological Sciences 274: 303-313.

[42] Kull, T., Hutchings, M.J. (2006): A comparative analysis of decline in the distribution ranges of orchid species in Estonia and the United Kingdom. - Biological Conservation 129: $31-39$.

[43] Larson, R. J., Larson, K. S. (1987): Observations on the pollination biology of Spiranthes romanzoffiana. - Lindleyana 2: 176-179.

[44] Maglocky, S., Feráková, V. (1993): Red list of ferns and flowering plants (Pteridophyta and Spermatophyta) of the flora of Slovakia (the second draft). - Biologia 48(4): 361385.

[45] Meekers, T., Honnay, O. (2011): Effects of habitat fragmentation on the reproductive success of the nectar-producing orchid Gymnadenia conopsea and the nectarless Orchis mascula. - Plant Ecology 212(11): 1791-1801.

[46] Molnár V. A. (ed., 2011): Magyarország orchideáinak atlasza. - Kossuth Kiadó, Budapest. 504 pp.

[47] Müller, I. (1988): Vergleichende blütenökologische Untersuchungen an der Orchideengattung Epipactis. - Mitteilungsblatt AHO Baden-Württemberg 20: 701-803.

[48] Neiland, M.R.M., Wilcock, C.C. (1999): Fruit set, nectar reward, and rarity in the Orchidaceae. - American Journal of Botany 85: 1657-1671.

[49] Nilsson, L. A. (1980): The pollination ecology of Dactylorhiza sambucina (Orchidaceae). - Botaniska Notiser 133: 367-385.

[50] Nilsson, L. A. (1981): The pollination ecology of Listera ovata (Orchidaceae). - Nordic Journal of Botany 1: 461-480. 
[51] Pecoraro, L., Girlanda, M., Kull, T., Perini, C., Perotto, S. (2013): Fungi from the roots of the terrestrial photosynthetic orchid Himantoglossum adriaticum. - Plant Ecology and Evolution 146(2): 145-152.

[52] Peisl, P., Forster, J. (1975): Zur Bestäubungsbiologie des Knabenkrautes Orchis coriophora L. ssp. fragrans. - Die Orchidee 26: 172-173.

[53] Petanidou, T., Duffy, K. J., Karatza, A., and Kantsa, A. (2013): Reduced fecundity in large populations of a Mediterranean orchid - Evidence for pollinator limitation. - Basic and Applied Ecology 14: 36-43.

[54] Potts, S.G., Biesmeijer, J.C., Kremen, C., Neumann, P., Schweiger, O., Kunin, W.E. (2010): Global pollinator declines: trends, impacts and drivers. - Trends in Ecology and Evolution 25: 345-353.

[55] R Core Team (2013): R: A language and environment for statistical computing. $\mathrm{R}$ Foundation for Statistical Computing, Vienna, Austria. http://www.R-project.org/

[56] Reinhard, H. R., Gölz, P., Peter, R., Wildermuth, H. (1991): Die Orchideen der Schweiz und angrenzender Gebiete. - Fotorotar, Egg 348 pp.

[57] Rybka, V., Rybková, R., Pohlová, R. (2005): Plants of the Natura 2000 network in the Czech Republic. - Olumouc, Praha.

[58] Steffan-Dewenter, I., Tscharntke, T. (1999): Effects of habitat isolation on pollinator communities and seed set. - Oecologia 121: 432-440.

[59] Steffan-Dewenter, I., Tscharntke, T. (2000): Resource overlap and possible competition between honey bees and wild bees in central Europe. - Oecologia 122: 288-296.

[60] Sulyok, J. (2011): Mocsári sisakoskosbor és házi méh (Apis mellifera). In: Molnár V., A. (ed.): Magyarország orchideáinak atlasza. - Kossuth Kiadó, Budapest. p. 60.

[61] Sulyok, J., Vidéki, R., Molnár V., A. (1998): Adatok a magyarországi Himantoglossumfajok ismeretéhez. - Kitaibelia 3(2): 223-229.

[62] Swarts, N.D., Dixon, K.W. (2009): Terrestrial orchid conservation in the age of extinction. - Annals of Botany 104: 543-556.

[63] Teschner, W. (1980): Sippendifferenzierung und Bestäubung bei Himantoglossum Koch. - Jahresberichte des Naturwissenschaftlichen Vereins Wuppertal 33: 104-116.

[64] Tóth, P. (2013): Magyar Méhészeti Nemzeti Program Környezetterhelési Monitoring vizsgálat 2012-2013. - Országos Magyar Méhészeti Egyesület.

[65] Visscher, K.P., Seeley, T.D. (1982): Foraging strategy of honeybee colonies in a temperate deciduous forest. - Ecology 63: 1790-1801.

[66] Vöth, W. (1989a): Die Bestäuber von Orchis papilionacea L. (Orchidaceae). - Linzer Biologische Beitraege 21: 391-404.

[67] Vöth, W. (1989b): Bestäubungsbiologische Beobachtungen an Orchis tridentata Scop. Die Orchidee 43: 280-283.

[68] Vöth, W. (1990): Effective und potentielle Bestäuber von Himantoglossum. Mittelungblatt AHO Baden-Württemberg 22: 337-351.

[69] Vöth, W. (1994): Bestäuber und Besucher der Blüten von Traunsteinera globosa (L.) Rchb., Orchidaceae, in Niederösterreich. - Linzer Biologische Beitraege 26: 133-148.

[70] Vöth, W. (1998): Orchis italica und die angetroffenen Insekten. - Die Orchidee 49: 219221.

[71] Vöth, W. (1999): Lebensgeschichte und Bestäuber der Orchideen am Beispiel von Niederösterreich. - Stapfia 65, Biologiezentrum, Oberösterreichisches Landesmuseum, Linz.

[72] Vöth, W. (2000): Gymnadenia, Nigritella und ihre Bestäuber. - Journal Europäischer Orchideen 32: 547-573.

[73] Wiefelspütz, W. (1970): Über die Blütenbiologie der Gattung Epipactis. - Jahresberichte des Naturwissenschaftlichen Vereins Wuppertal 23: 53-69. 